\title{
Evaluation of Primary Care Dentist Service in the Implementation of Jaminan Kesehatan Nasional (JKN) in Central Java and Yogyakarta
}

\author{
Hendrartini J*., Hanindriyo L. \\ Department of Preventive and Community Dentistry, Faculty of Dentistry, Universitas \\ Gadjah Mada, Jl. Denta, Sekip Utara, Depok, Sleman, Yogyakarta, 55281, Indonesia \\ *e-mail: yhendrartini@ugm.ac.id
}

\begin{abstract}
Evaluation for the capitation payment system to the primary care dentist contracted by the Indonesian National Health Security Agency (BPJS Kesehatan) needs to be done as a basis for future improvements. This study aimed in describing the utilization of dental services; the average services fee received for each type of service; the level of patient satisfaction on dental service; the dentist level of satisfaction on the capitation payment system; and analyzing the suitability of capitation rates with generally accepted rates in the area of Central Java and Yogyakarta. Quantitative primary data was collected through questionnaires by dentists and their patients. While qualitative primary data was collected by Focus Group Discussion (FGD). Dentists involved in the FGD were selected by purposive sampling by local Indonesian Dental Association (PDGI) chairman. Secondary data of independent primary care dental practice was taken from BPJS Kesehatan. As a result, $26.76 \%$ of primary care dentists have a small number of insured patients (2001-5000). Real unit cost average was around IDR350,000 per visit. Most of the subjects $(73.77 \%)$ stated that they are quite satisfied with the capitation payment system, but not with the nominal value. Most of the patients (98.5\%) were satisfied with the dental services. In conclusion, capitation nominal value needs to be adjusted with a detailed benefits packages. Enrollment-based membership mechanism needs to be evaluated. Routine monitoring and evaluation meetings between BPJS Kesehatan and primary care dentist needs to be done every 3 months, accompanied by PDGI.
\end{abstract}

\section{Keywords}

Citation: Hendrartini J., Hanindriyo L. (2018). Evaluation of Primary Care Dentist Service in the Implementation of Jaminan Kesehatan Nasional (JKN) in Central Java and Yogyakarta. In F. Jajah \& H. Susilowati (Eds.), UGM Digital Press Health Sciences: Vol. 1. Proceeding of the 2nd International Conference on Health Sciences, (pp. 19-30).

Published: October, 2018
Capitation, National health insurance, Universal coverage, Pre-payment system, Primary care dentist.

\section{Introduction}

The national health insurance system (JKN) was officially implemented in Indonesia since January 1, 2014, in accordance with the mandate of Law No. 40/2004 on National Social Security System and Law No. 24/2011 on Social Security Agency (BPJS) [1]. This system obliged all citizens of Indonesia to be insured by the JKN gradually until the year 2019 (universal coverage). This system offered comprehensive benefits 
that include promotive, preventive, curative, and rehabilitative services. Health services organized with several levels of referral system from primary, secondary, and tertiary.

Therefore, the strengthened role of primary physicians and primary care dentists as the gatekeeper in the health care provider system is one of the indicators of the successfulness of this program. One of the benefits offered by JKN system is dental health services. The insured dental services were expected to remove the main barriers of accessing dental services leading to the improvement of the dental health status of the people of Indonesia.

Evaluation of the capitation payment system which has been 1.5 years applied to the primary care dentist contracted by the Indonesian National Health Security Agency (BPJS Kesehatan) needs to be done as a basis for future improvements. This study focused on the region of Central Java and Yogyakarta, as it reflects the level of competition dentist high, easy access, and the participants were many, so hopefully will be able to represent and address issues faced by dentists.

This study aimed in describing the utilization of dental services; the average services fee received for each type of service; the level of patient satisfaction on dental service; the dentist level of satisfaction on the capitation payment system; and analyzing the suitability of capitation rates with generally accepted rates in the area of Central Java and Yogyakarta.

\section{Methods}

This study was a descriptive study, the results of this study will be used to draw up a plan for the improvement of dental services. The method used in this study is a mixed method. Variables investigated in this study include the satisfaction of primary care dentist, utilization of dental services in the primary level, the level of patient satisfaction, patient waiting time, and the cost of dental health services. The study population was primary care dentists contracted by BPJS Kesehatan accepting capitation payments in the region of Central Java and Yogyakarta. Proportionate-random sampling was used to ensure the representativeness of population within this region (5 Districts: Yogyakarta, Kebumen, Klaten, and Semarang). Quantitative primary data was collected through questionnaires [2,3] by the dentists and their patients (20 patients were taken from each dentist). While qualitative primary data was collected by Focus Group Discussion (FGD). Dentists involved in the FGD were selected by purposive sampling technique by local Indonesian Dental Association (PDGI) chairman. FGDs were done for primary care dentists in Kebumen, Semarang, Yogyakarta, and Klaten. Secondary data of the independent primary care dental practice in the region of Central Java and Yogyakarta was taken from BPJS Kesehatan. Data was analyzed using quantitative data analysis, qualitative analysis as well as mixed methods.

\section{Results}

\subsection{Quantitative Result}

\subsubsection{Description of the Top 10 Dental Diseases}

Based on the results shown in Figure 1, this study found that the top 10 major diagnoses of oral diseases suffered by BPJS insured patients who have made dental visits to receive treatment at the primary care dentist are as follows, necrotic pulp, dentinal caries, pulpitis, impaired tooth eruption, chronic periodontitis, periapical abscess without sinus, root persistency, chronic apical periodontitis, tooth loss and tooth impaction. The results showed that the number of patients with the same diagnosis in August was always higher than in September 2015. 


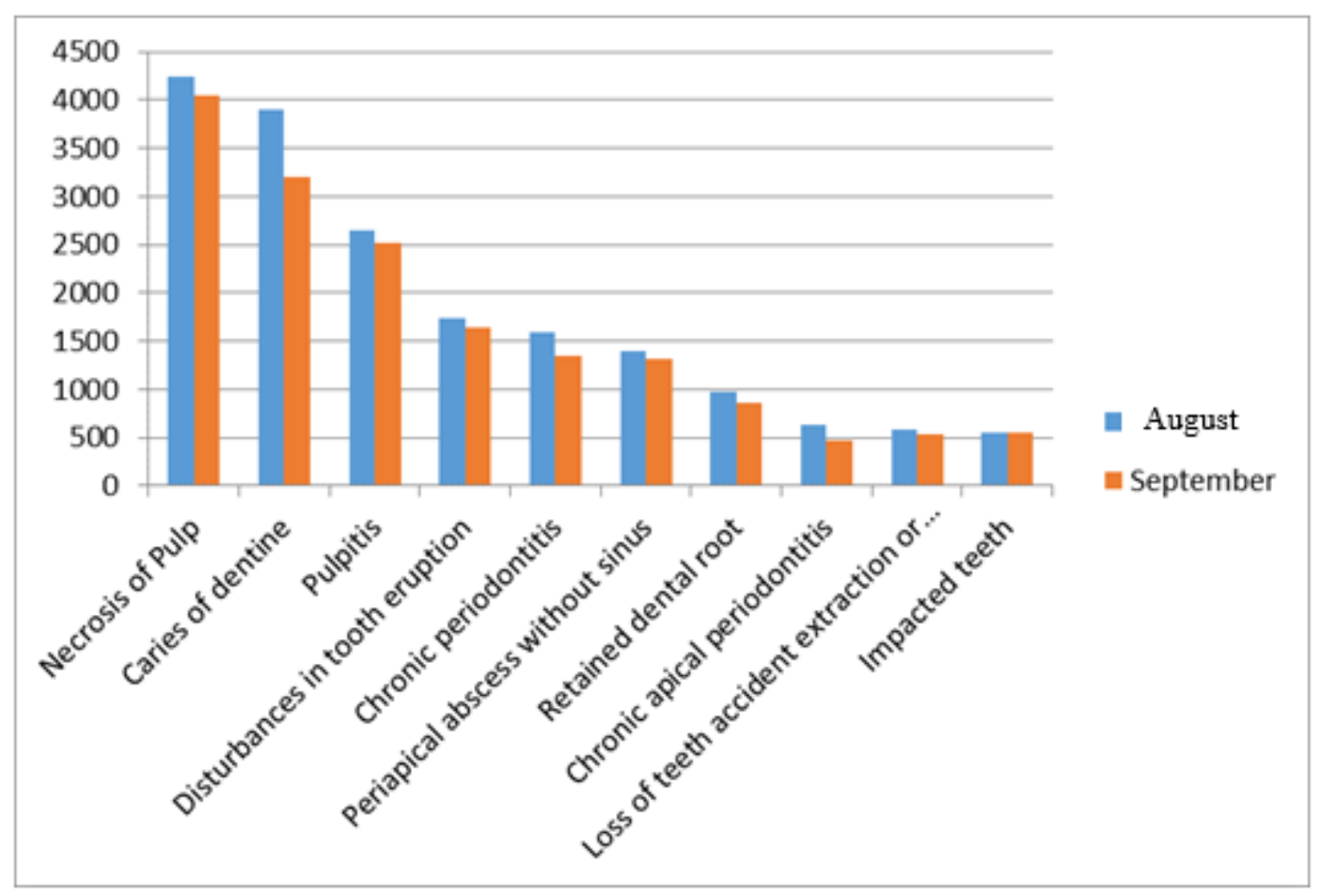

Figure 1. Description of the Top 10 Dental Diseases

\subsubsection{Description of dental insured patients}

This study categorized its dental insured patients in the primary care dentists into five categories: 'Very Few' (membership of less than 2000 people), 'Little' (2 001 people to 5000 people), 'Fair' (5 001 people to 8000 people), 'Many' (8 001 people to 10000 people), 'Very Much' (more than 10001 people). Figure 2 showed that out of a total of 284 primary care dentists in the region of Central Java and Yogyakarta, the largest proportion of dentists (26.76\%) has a membership that is classified as 'Little', but on the other hand the number of dentists who have 'Many' and 'Very Much' also shows a fairly high proportion (15.49 \% / 44 and $14.08 \%$ / 40).

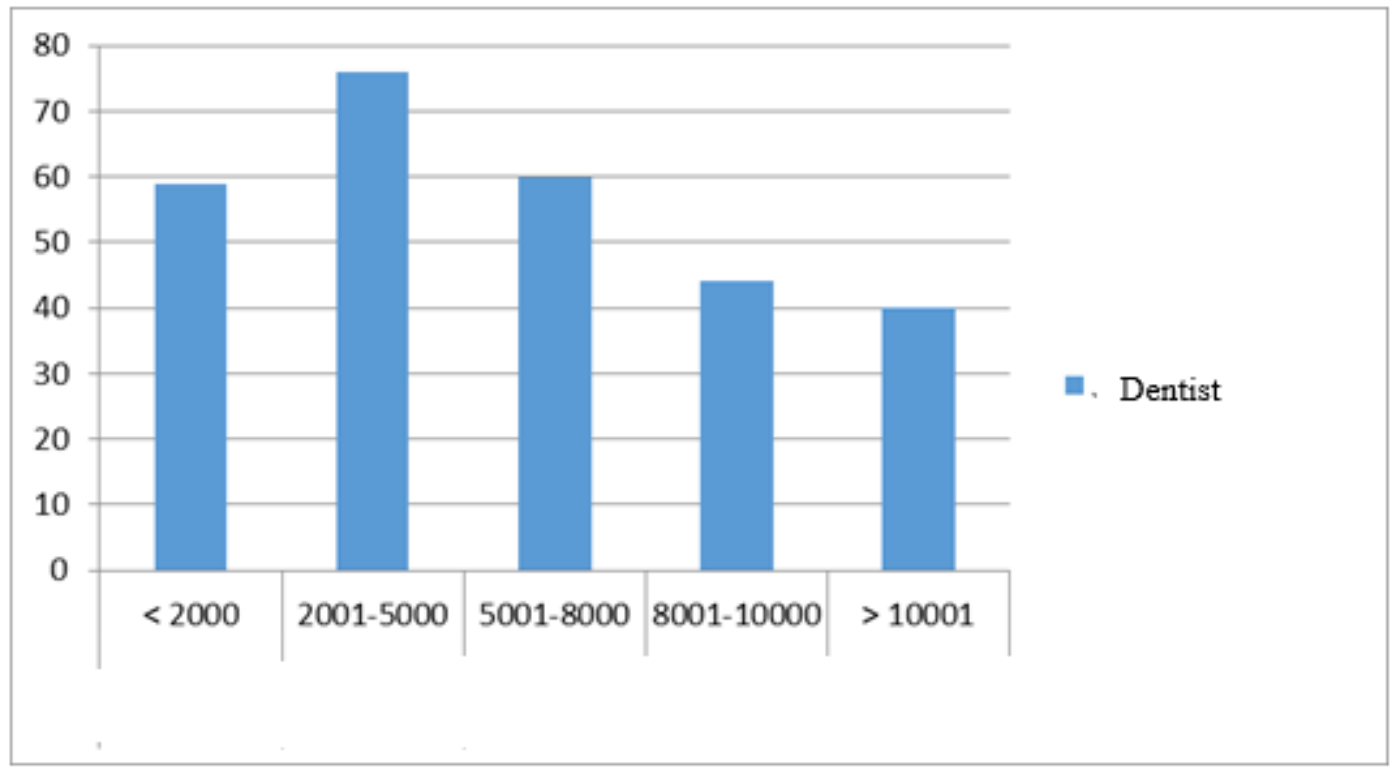

Figure 2. Description of dental insured patients 


\subsubsection{Description of Utilization}

The utilization rate is one of the most important indicators related to the evaluation process and planning of oral health programs, particularly in the era of National Health Insurance. The results of this study, as shown in Figure 3, showed that most dentists in the region of Central Java and Yogyakarta (44.01 \% / 125) in September had a utilization rate of about $1 \%$. While $35.21 \%(100)$ had a utilization rate of $1-2 \%$, and only $5.63 \%(16)$ has a utilization rate of more than $4 \%$ in August. Overall the average level of dental visits in the region of Central Java and Yogyakarta in August was $1.89 \%$ and $1.51 \%$ respectively in September. The utilization rate indicates that the utilization rate of dentists still in line with the utilization rate used in the calculation of primary care dentist capitation in 2014.

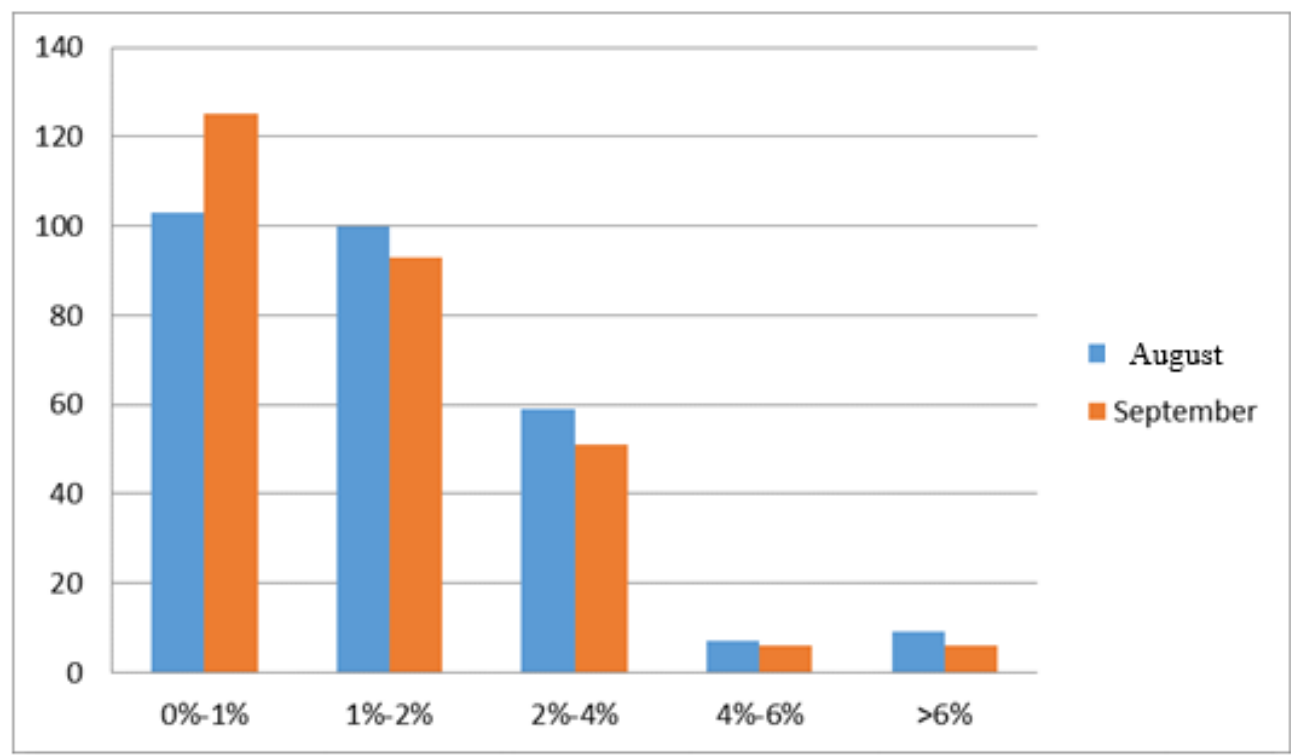

Figure 3. Description of Utilization

\subsubsection{Description of Referral Activities}

The results showed that within August and September the referral patterns of primary care dentist have almost the same percentage. Figure 4 also shows that most referral activities by primary care dentist were in the range of $1 \%$ to $10 \%$ of all the cases they received. A high percentage of referral activities $15 \%$ to $20 \%$ or more) was done only by a minority of primary care dentists in the region of Central Java and Yogyakarta.

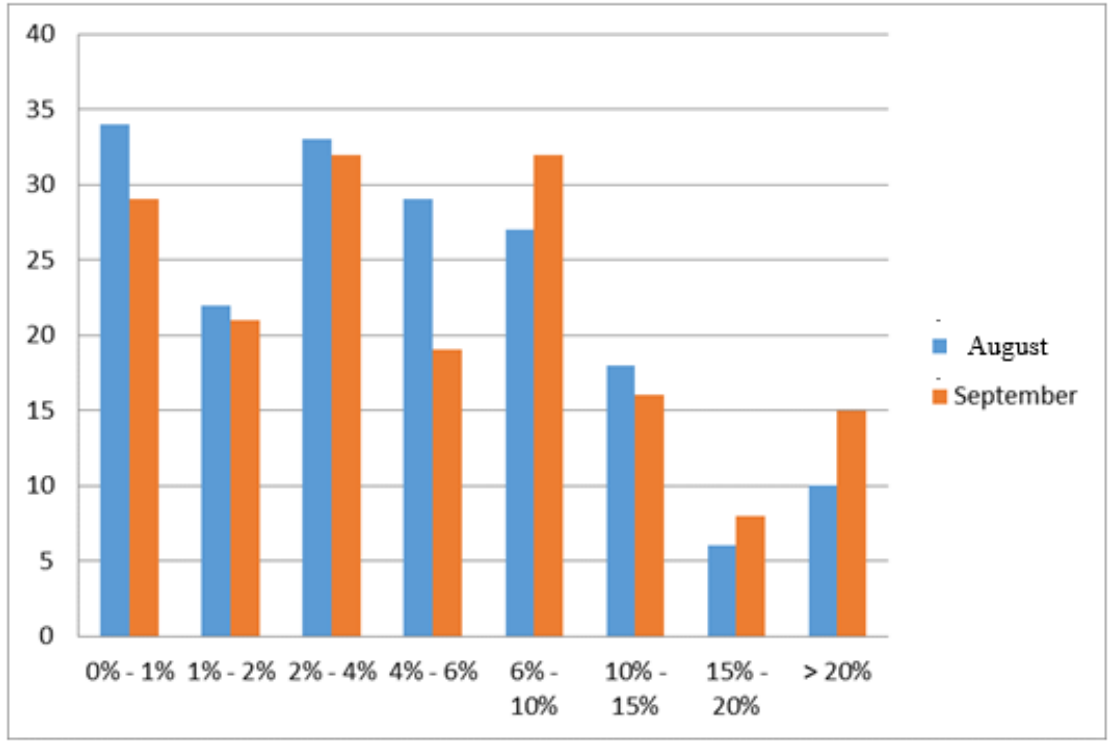

Figure 4. Description of Referral Activities 


\subsubsection{Description of Real Unit Cost}

The real unit cost is one of the indicators used to assess the adequacy of the capitation value received by the provider of the National Health Insurance program. The nominal amount of the real unit cost shows the amount received by the primary care dentist in providing a single dental care visit based on the value of capitation and utilization. Figure 5 showed that the real average unit cost of primary care dentists in Central Java and Yogyakarta within August and September 2015 was approximately IDR350,000 per visit. This amount was higher than the average cost of private dental practice.

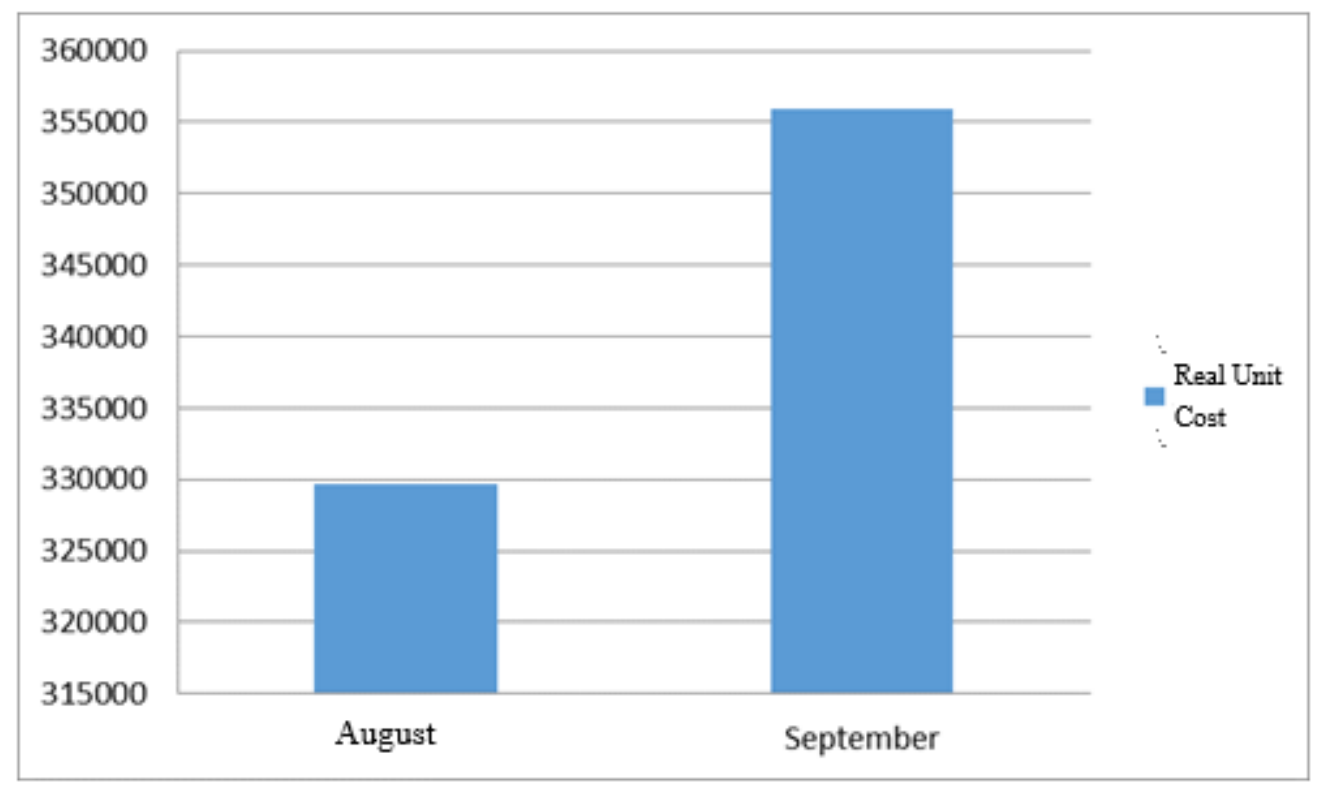

Figure 5. Description of Real Unit Cost

\subsubsection{Real Unit Cost Categorization per Patient}

It is known that the highest proportion of real unit cost a nominal amount per patient in August was less than IDR100,000 (27.5 \% / 78). While the highest category of real unit cost per patient (> IDR350,000), was obtained by $15.14 \%$ / 43 dentists either in August or September. It can be concluded that a similar pattern occurred in August and September. The lowest proportion of the real unit cost per patient value was IDR301,000 to IDR350,000.

\subsubsection{Monthly Acceptance of Capitation}

The primary care dentists monthly acceptance of capitation in Central Java and Yogyakarta during August and September 2015 was categorized as; less than IDR1,000,000, IDR1,000,000 to IDR2,000,000, IDR2,100,000 to IDR5,000,000, IDR5,100,000 to IDR8,000,000, IDR8,100,000 to IDR1,200,000, IDR12,100,000 to IDR15,000,000, IDR15,100,000 to IDR18,000,000, IDR18,100,000 to IDR20,000,000, More than IDR20,100,000 as shown in Figure 6.

The study showed that the highest proportion of capitation funds acceptance was in the range of IDR2,100,000 to IDR5,000,000 (20.07 \% / 57 in August). Following, was in the category of IDR8,100,000 to IDR12,000,000 with the proportion of $15.49 \%$ / 44 during the period of August and September. While the acceptance of capitation within the highest category (more than IDR20,000,000) was accepted by $14.08 \%$ / 40 primary care dentists in September. The mean acceptance of capitation funds in August was IDR11,041,288, while in September was IDR11,340,218. 


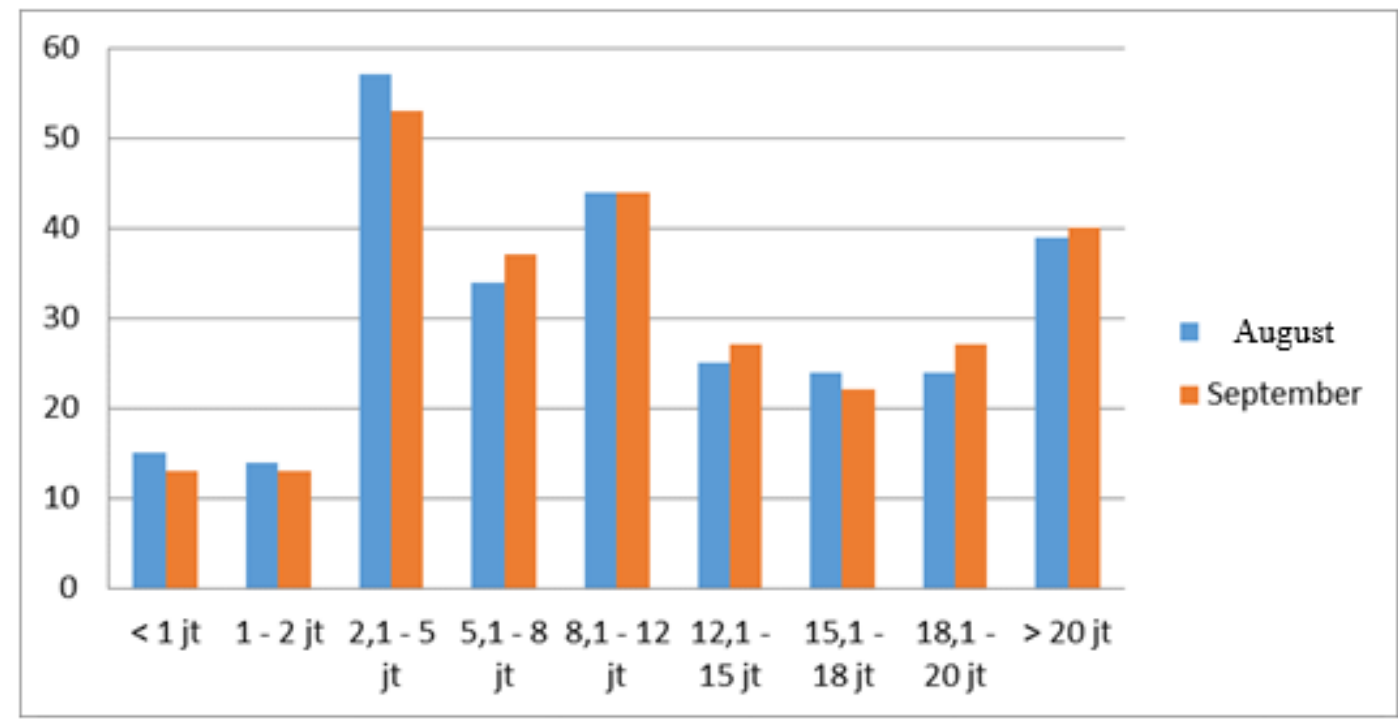

Figure 6. Monthly Acceptance of Capitation

\subsubsection{Dentists Satisfaction on Capitation Payment}

Questionnaires were used to assess the dentist's satisfaction on capitation payments. The questionnaire was completed by 122 primary dentists contracted by BPJS Kesehatan in major cities of Central Java and Yogyakarta (Semarang, Yogyakarta, Kebumen, and Klaten). The results shown in Figure 7 showed that the majority of primary care dentist in Central Java and Yogyakarta felt quite satisfied with the capitation payment ( $73.77 \%$ / 90 people). A total of $25.41 \%$ (31 people) said that they were satisfied by the capitation payment, and the remaining $0.82 \%$ (1 person) states dissatisfied. It is known that the majority of primary care dentist was satisfied on every questionnaire item statement except for statement No. 8 (69.67\%). The statement was about the current amount of capitation, which is IDR2,000 per person per month.

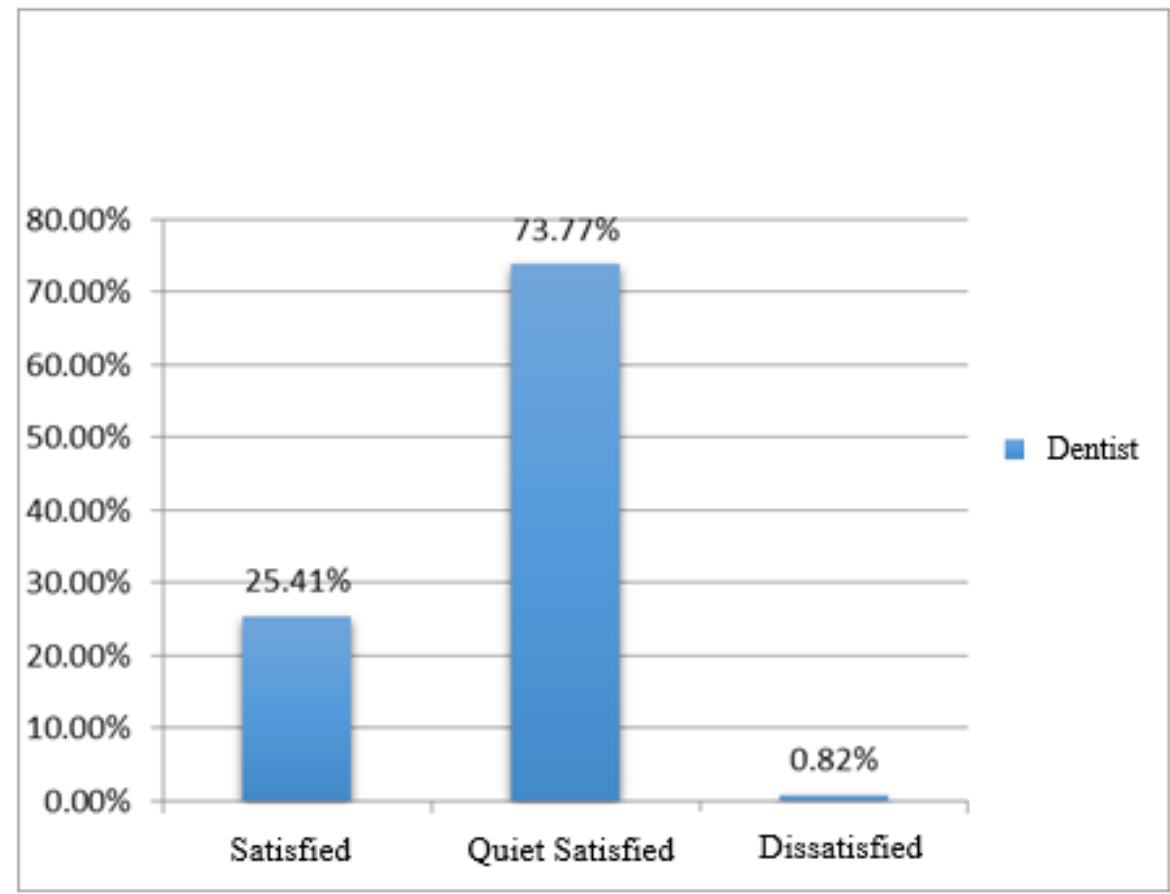

Figure 7. Dentists Satisfaction on Capitation Payment 


\subsubsection{Patient's Satisfaction on Primary Dental Service}

Questionnaires were used to assess patient satisfaction on primary dental service. The questionnaire was completed by 200 patients as the representative from 4 major cities in Central Java and Yogyakarta, which was held in Semarang, Yogyakarta, Kebumen, and Klaten. Figure 8 showed that most of the patients satisfied with the services of a primary care dentist (98.5 \% / 197 people). A total of $1.5 \%$ (3 people) stated quite satisfied with the services from a primary care dentist. None of the patients were dissatisfied with the services of a primary care dentist. In general, the results showed that most of the patients agree on every item questionnaire with a statement but did not agree to the unwillingness of the dentist to provide a referral letter and a long waiting time for treatment.

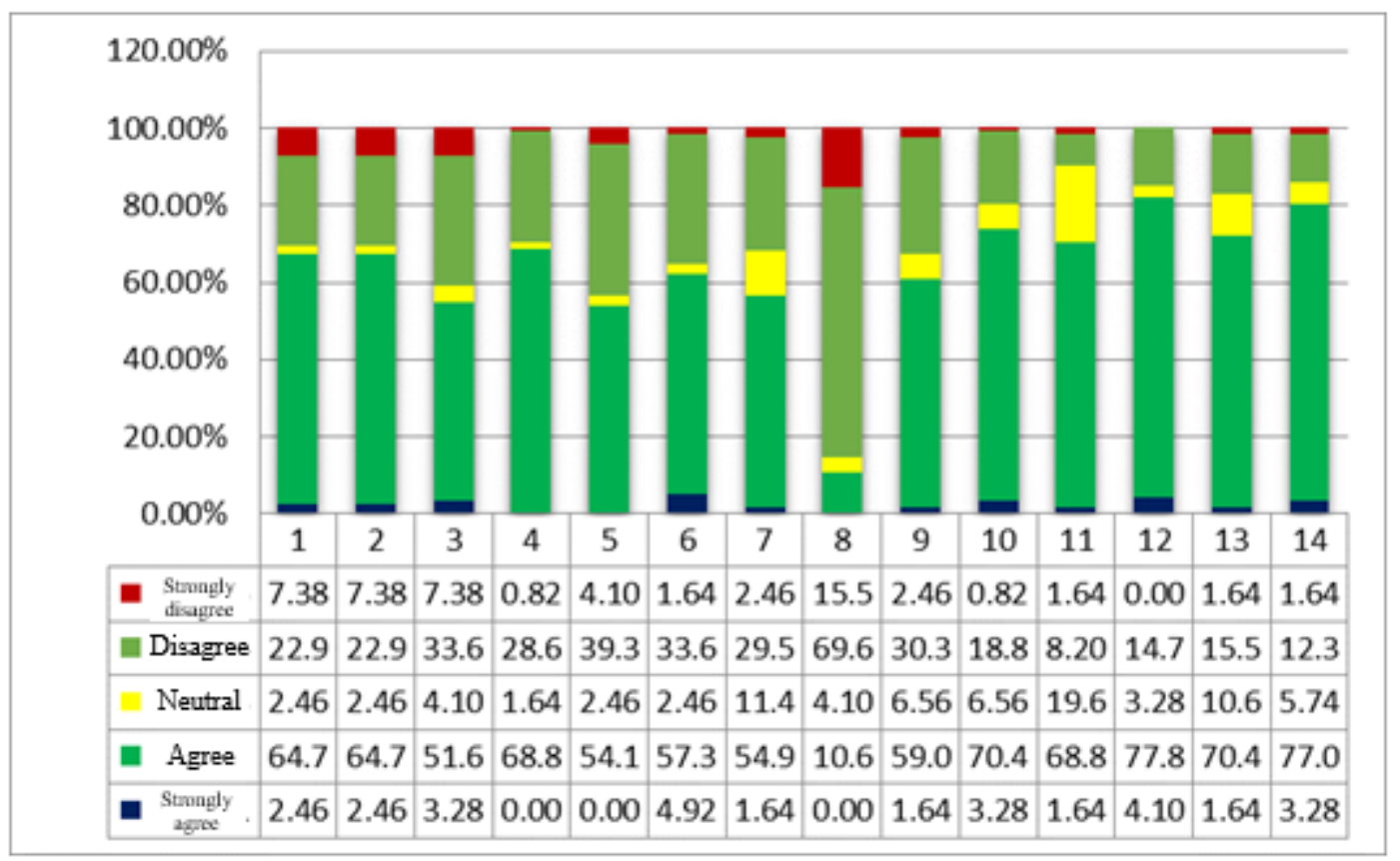

Figure 8. Patient's Satisfaction on Primary Dental Service

\subsection{Qualitative Result}

\subsubsection{FGD Participant Characteristic}

As shown in Figure 9, it is known that most of the dentists joining the FGD have several insured patients ranged between 5 001-8 000 people (27.27 \%). The proportion of FGD participants with the number of insured patients ranging between 2001-5000 and 8001-10 000 were $21.21 \%$. A total of $16.67 \%$ of the FGD participant has the number of more than 10000 people, while as much as $13.64 \%$ of the FGD participants have less than 2000 insured patients. 


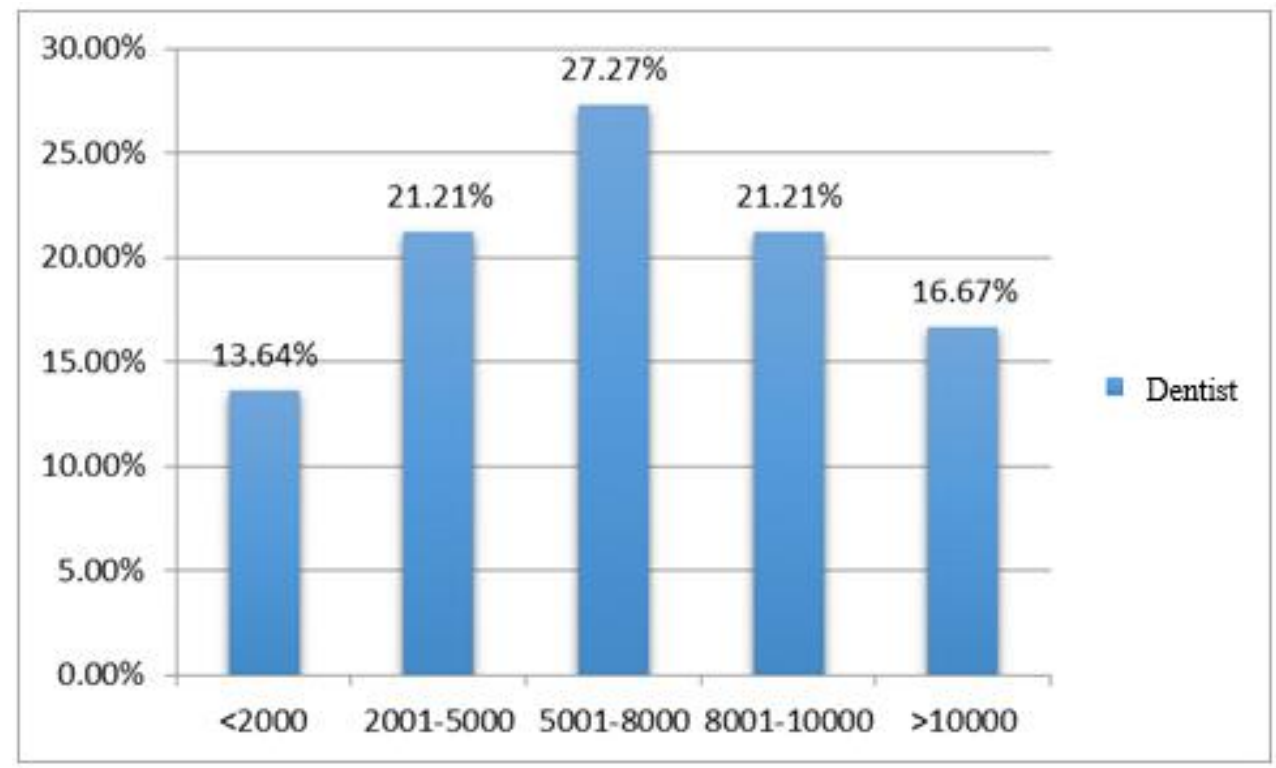

Figure 9. FGD Participant Characteristic

Figure 10 showed that most of the primary care dentist joining the FGD have been contracted by BPJS Kesehatan for 1-2 year (51.61 \%). Only $1.61 \%$ of the FGD participant has less than 1-year experience of cooperation with BPJS Kesehatan. While as many as $46.77 \%$ of the FGD participants have worked together with BPJS Kesehatan for more than 2 years. There is a possibility that the primary care dentists have been contracted by Askes or Jamsostek before they were contracted by BPJS Kesehatan.

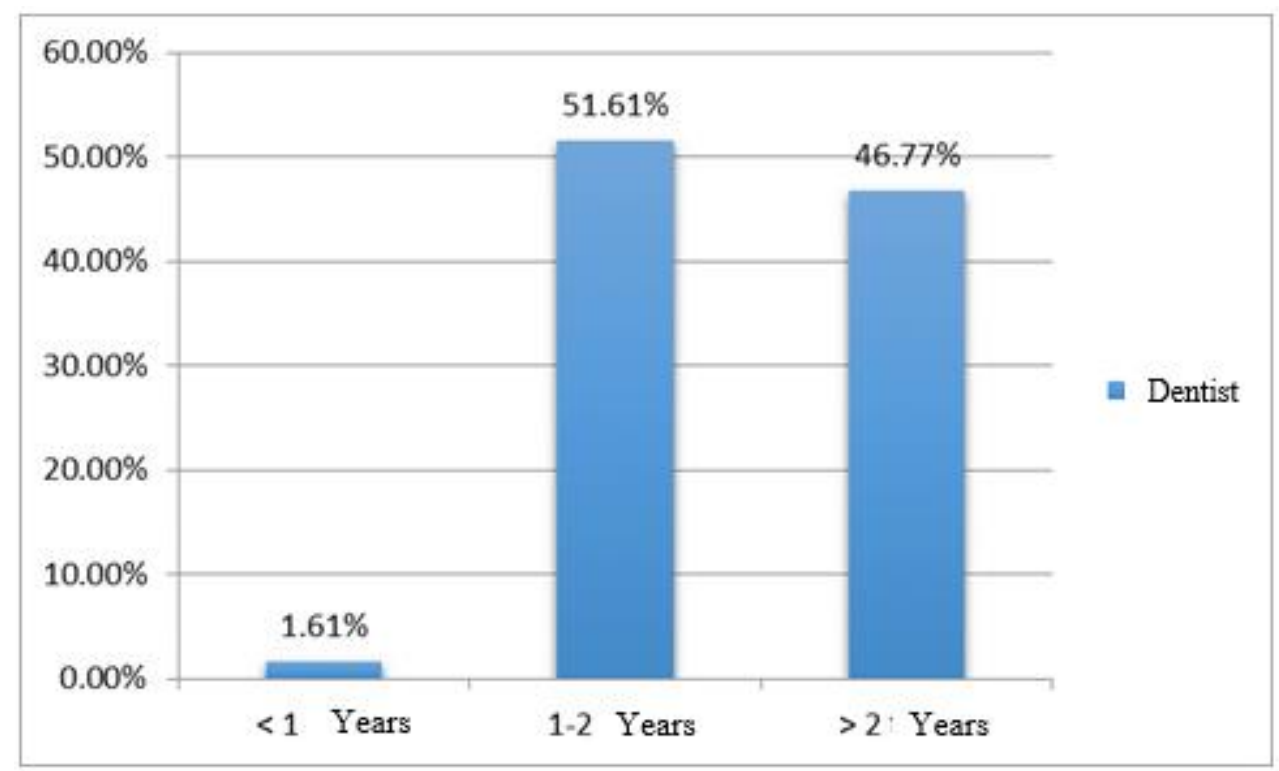

Figure 10. Working experience with BPJS Kesehatan / PT. Askes

\subsubsection{FGD Result}

\subsubsection{Contact with BPJS Kesehatan}

FGD results indicated that individual (per dentist) monitoring and evaluation activities were done very rarely. This led to weak feedbacks in improving the quality of services that should be a BPJS Kesehatan concern as the insurer. The dentist wants more intensive communication with BPJS Kesehatan as part of the monitoring and evaluation. It is hoped that when there are problems or very important things that need to be solved, it can be directly addressed. FGD results indicate that most of the dentist felt that there was 
no transparency in the legal contractual process since there was no socialization of the contents prior to the contract was signed. Another weakness of the contract is the clauses multi-perception and dentists were forced to interpret themselves. This condition causes the dentist felt that they must immediately sign the agreement contract without reading the contents of the document in detail.

\subsubsection{Membership}

The most prominent issue was the fluctuating data on the number of insured patients in each month, moreover, it can even be decreased drastically. The dentists felt than the BPJS Kesehatan was not accountable because the data changes were not regularly informed to the dentist and can only be detected by P-care. Currently, the primary care dentists are faced with the problem of membership associated with the presence of the clinic. In general, FGD results showed that the dentists understood that the insured patients have the freedom to choose the dentist, but on the other hand, BPJS Kesehatan was considered to be intransparent since they do not show the date of the insured patients that have signed up.

The results of this FGD showed that the number of insured patients was important to be considered as an integral part of the service mechanism. Some dentists say that the market mechanism and the lack of control by professional organizations in mapping the location of the practice led to the unequal number of insured patients as they expected. Some dentists mentioned that the participants should be limited to a minimum and maximum amount. This must be done in order to assure the service to run more optimally and to cover the operating costs.

\subsubsection{Benefit Package}

Some dentists have different opinions about preventive care. In general, the results of FGD expressed dentists doubts to provide preventive services. Basically, the dentists do not mind to perform scaling treatment, but most of them prefer this treatment to be considered as curative rather than preventive category. The dentists were still in confusion about the category of light cure composite resin as a part of curative treatment or aesthetic one. The dentist has a different understanding of whether there should be cost sharing or not on composite fillings.

Generally, the result of FGD described the dentist's problems about the limit level of root canal treatment that can be done in the primary care level. The need for supporting services such as x-rays should be taken into consideration by BPJS Kesehatan for this treatment. In general FGD results indicate that the service for partial dental prosthesis can be well served by the dentists, they expect the reimbursement period by the BPJS could be accelerated.

\subsubsection{P-care}

The dentists have a good ability to use P-Care, but sometimes they still have problems with the internet network or server. They also did not know the exact names of the insured patients enrolled in their place. Data on treatments and elements of teeth were also not available on the P-care. Therefore, there is a proposal of adding several data such as the identity of the patients, the treatment for the teeth and tooth element to facilitate the evaluation of dental services, report generation, and referral of patients.

\subsubsection{Capitation Payment}

Nowadays, capitation payments to the primary care dentist still encounter many different kinds of constraints, such as, the capitation nominal value was assumed to be too small by primary care dentists, the delay in the delivery of the certificate of payment by BPJS Kesehatan, an incompatibility between the payment and the number of insured participant, the lack of details of the payment by BPJS Kesehatan, progressive payment of taxes which perceived to be burdensome for primary care dentist, and the reconciliation payment that has not gone well.

\section{Discussion}

One of the benefits offered in the JKN system is dental health services. This system was expected to remove the main barriers of accessing dental services and improving the dental health status of the people in Indonesia. In many countries, dental services benefit was provided in an advanced or even excluded from the benefits of health insurance and to be separately managed. One of the reasons is the expensive cost of dental care. Including dental care at the primary level of service leads the dentist to become a primary care 
provider. On the other hand, JKN premium amount was limited, therefore, this type of primary dental services offered was also limited.

As the consequences of the above-mentioned policies, most of the patients will be treated by primary care dentist contracted by BPJS Kesehatan in the future. Primary care dentist payment method was stipulated in the Presidential Regulation No. 12 of 2013 Article 39 with capitation method as the model [4]. The capitation payment system is a new thing for dentists particularly in the private practice. This system will change the system of provider payment from retrospective fee for service system to a prospective payment system using capitation models for primary care and INA CBG's for secondary and tertiary levels of services.

The shift towards a system of capitation payments was based on various evaluations indicating that the fee for service payment method was known to cause inefficiencies and increased costs of health care [5]. In the fee for service (FFS) model of payment, doctors do not bear the financial risks, therefore, overutilization and supply-induced demand often occur in the provision of health services [6]. In contrast, the capitation payment model is expected to improve the efficiency of health care costs by including primary care physicians in a position to bear some or all the financial risks associated with the use of resources in health services $[7,8]$.

Capitation rates were calculated based on the number of registered insured patients, regardless of the type and quantity of health services provided. Capitation for primary dental care in JKN program set by the government was IDR 2000 per person per month (Minister Regulation No. 69/2013) with an ideal membership ranges between 8 000-10 000 insured patients. This leads to varied reactions from the profession of dentistry that is generally triggered by a lack of understanding of the dentist towards capitation payment system. Capitation was determined based on the unit cost of dental care, which is generally suitable for dental service utilization. The small number of dental services utilizations led to a low capitation nominal value.

The position of primary care dentists was very important for early disease prevention. The existence of dentists in primary health care will help to prevent the insured patients of BPJS Kesehatan in order not to experience a more severe illness that is costlier to cure. Currently the role of primary care physician faces a paradoxical situation, on the one hand, was neglected and less attractive, but on the other hand was demanded to act as a gatekeeper in the cost control services and also demanded a coordinative and integrative role in the provision of health services for patients including referral services to medical specialists and hospitalization. This condition certainly becomes a challenge for BPJS Kesehatan. BPJS Kesehatan needs the contributions from all stakeholders to change towards an improvement of the primary health care delivery.

The most doctors felt under pressure due to the treatment limitation in the capitation system and this leads to the under-treatment of patients which can cause patient dissatisfaction $[9,10]$. Capitation payments also encourage physicians to reduce health service delivery [11]. Therefore, it is necessary to evaluate the capitation payment system that is applied to the primary dentist contracted by BPJS Kesehatan as a basis for future improvements to the betterment of the system.

Based on the result shown in Figure 2, it is known that most of the dentist involved in this study were having relatively few insured patients, while some of them have 'Many' and 'Very Much'. This fact was supported with the results from the FGD which stated that most of the dentist with few insured patients have an objection with the enrollment-based system for the dental provider membership. It made the socalled 'old-player' dentist in this system can easily have much more insured patients as a result of the changing insurance system. Therefore, they were asking a possibility of the role from the IDA nor the District Health Office in the mapping and distributing the patients to the contracted providers.

Furthermore, Figure 3 illustrated that the average utilization rate of dental treatment was relatively low (1\% to $2 \%$ ). This result shows the possibility of the low awareness of the population for oral health as well as the assumptions of the unimportance of taking good care of oral health. On the other hand, it must be realized that oral health has not become a health priority for a population which still have many general health issues to be considered generally happened in a developing country like Indonesia.

The application of the capitation method assumed to enhance the tendency of referring unnecessary primary cases to the second level due to the moral hazard of the primary care provider [11]. On the other hand, contrary results were found within this study. Based on the result in Figure 4, most of the primary care dentist had a relatively low referral rate. While only a small proportion of them was reported to have a high rate of referral activities. This might be explained that the primary care dentist whose most of them were relatively new to the system was trying their best in complying with the contracts, rules, regulations as well as rewards and punishments regarding the referral system established by the BPJS. The previous study shows that moral hazards in terms of referral activities tend to happen in providers who have been 
in the system for a considerable period of time $[12,13,14]$. Therefore, a study to evaluate particularly the referral activities within the system of JKN needs to be done in order to improve the quality of the system in the future.

The capitation nominal value for a primary care dentist was enacted to be IDR2,000 per person per month since the year of 2014. This value was advocated by IDA with the assumption of each primary care dentist ought to have 8 000-10 000 insured dental patients. Within this assumption, the real unit cost for treatment would appropriate for dental expenditure. On the other hand, since the BPJS employed an enrollment system for the primary care dental provider, as shown in Figure 5, there is still primary care dentist whose only have under 200 person as their insured dental patients. This fact caused the existence of a very low real unit cost value (below IDR100,000) which certainly cause financial loss for the dentist. On the contrary, for the dentist who has many more insured dental patients, they can have higher real unit cost value which can be considered to be more than the benefit table. Most of the dentist involved in this study received monthly capitation payment of around IDR 2 to 5 million as shown in Figure 5 . This certainly shows that most of the dentists were having a low number of insured dental patients.

Most of the dentist, as shown in Figure 7 were satisfied with the capitation payment system. Based on the result from the qualitative data, they were mostly satisfied with the payment punctuality, the accurate calculation, but on the other hand, they were dissatisfied by the nominal value of it (IDR2,000). This is justifiable since most of the dentists were only having insured dental patients for less than 1,000 people. Therefore, the urgency of distributing dental insured patients needs to consider in the future. Furthermore, within this imperfect system, the dentists still showed that they were keeping their responsibilities in giving their best for their patients. This was confirmed by the satisfaction level of their patients shown in Figure 8.

\section{Conclusion}

The results from this research suggest that capitation nominal value needs to be adjusted with detailed benefits packages While enrollment-based membership mechanism needs to be evaluated. Moreover, routine monitoring and evaluation meetings between BPJS Kesehatan and primary care dentist needs to be done every 3 months, accompanied by PDGI (Indonesian Dental Association).

Acknowledgments The authors declare that they have no conflict of interests. This study was supported by a grant-in-aid from BPJS Kesehatan. We are profoundly grateful to the study participants for their assistance.

\section{References}

1. Presidential Office of Republic Indonesia. PERPRES No. 12/2013: Tentang Badan Pelaksana Jaminan Sosial Bidang Kesehatan [Presidential Regulation: About the implementing body of social security in health]. Jakarta; 2013. pp. 1-3. [in Bahasa Indonesia]. https://bpjskesehatan.go.id/bpjs/dmdocuments/52b113a232ac4859fafb2db7beac88b0.pdf

2. Davis A, Ross W, John E. Development Of A Dental Satisfaction Questionnaire For The Health Insurance Experiment 1982, Santa Monica, CA, RAND Corporation; 1982. pp. 59-60. https://www.rand.org/pubs/reports/R2712.html

3. Hashim R. Patient satisfaction with dental services at Ajman University, United Arab Emirates. Eastern Mediterranean Health Journal 2005;11(5):913-921. https://www.ncbi.nlm.nih.gov/pubmed/16761661

4. Ministry of Health of the Republic of Indonesia, PERMENKES No. 69 Th. 2013: Tentang standar tarif pelayanan kesehatan pada fasilitas kesehatan tingkat pertama dan fasilitas kesehatan tingkat lanjutan dalam penyelenggaraan program jaminan kesehatan. [PERMENKES No. 69, 2013 on health service tariff rates at first level health facilities and advanced health room in the implementation of health insurance program] 2013; Jakarta pp. 2-3 [in Bahasa Indonesia].http://www.depkes.go.id/resources/download/general/PMK\%20No.\%2069\%20Th \%202013\%20ttg\%20Tarif\%20Pelayanan\%20Kesehatan\%20Program\%20JKN.pdf 
5. Kongsvedt PR. Essential of managed health care 6th ed. Jones and Bartkete Pub. Burlington MA; 2013. pp. 86-110. http://www.jblearning.com/catalog/9781449653316/

6. Madden D, Nolan A, Nolan B. GP reimbursement and visiting behaviour in Ireland. J Health Econ. 2005, 14 (10): 1047 - 1060. https://www.ncbi.nlm.nih.gov/pubmed/15791674

7. Barnum H, Kutzin J, Saxenian H. Incentives and provider payment methods. Working paper no. 14053. Human Resources Development and Operation Policy. World Bank; 1995. pp. 6-7. http://documents.worldbank.org/curated/en/748491468766812001/Incentives-and-providerpayment-methods

8. Thabrany H. Rasional Pembayaran Kapitasi. [Rationale for Capitation Payments]. Yayasan Penerbitan Ikatan Dokter Indonesia. Jakarta; 2000. pp. 45-50. [in Bahasa Indonesia] https://catalogue.nla.gov.au/Record/82046

9. Grumbach K, Osmond D, Vranizan K, Jaffe D, Bindman AB. Primary care physicians' experience of financial incentives in managed care systems. New England Journal of Medicine 1998;339(21):1516-1521 http://www.nejm.org/doi/full/10.1056/NEJM199811193392106

10. Armour BS. Physician financial incentives in managed care: Resouce use, quality and cost implication, disease management \& health outcomes. 2003;11(3):139-147. https://link.springer.com/article/10.2165/00115677-200311030-00001

11. Christianson J, Leatherman S, Sutherland K. Financial incentives, healthcare providers and quality improvements: A review of evidence. QQUIP. The Health Foundation London; 2007. p. 30-39. https://health.org.uk/publication/financial-incentives-healthcare-providers-and-qualityimprovements

12. Boland P. The capitation sourcebook: A practical guide to managing at risk arrangements. Boland Health Care Inc. California $\quad 1996$; pp. https://books.google.co.id/books?id=s5JY5pYdgEAC\&dq=The+Capitation+Sourcebook:+a+practi cal+guide+to+managing+at+risk+arrangements,+Boland+Health+Care+Inc.,+1996,+California\&hl=id\&source=gbs_navlinks_s

13. Harris RV, Ashcroft A, Burnside G, Dancer JM, Smith D, Grieveson B. Job satisfaction of dental practitioners before and after a change in incentives and governance: A longitudinal study. British Dental Journal 2009; 207(E4):1-7 https://www.nature.com/articles/sj.bdj.2009.605

14. Hendrartini J. Model Kinerja Dokter dengan Pembayaran Kapitasi dalam Program Asuransi Kesehatan. [Doctor's working performance by capitation payment system within the health insurance program]. [Dissertation]. Program Doktor Fakultas Kedokteran, Universitas Gadjah Mada, Yogyakarta; 2010. p. 103-107 [in Bahasa Indonesia] http://etd.repository.ugm.ac.id/index.php?mod=penelitian_detail\&sub=PenelitianDetail\&act=vie w\&typ=html\&buku_id=49431 